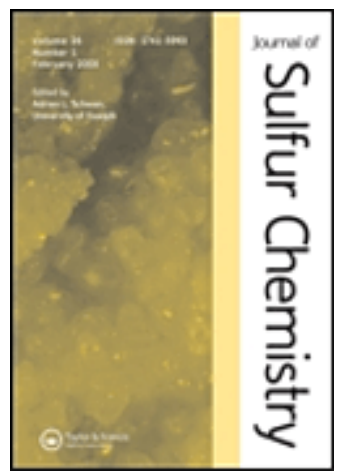

The synthesis of polymeric sulfides by reaction of dihaloalkanes with sodium sulfide

\begin{tabular}{|r|l|}
\hline Journal: & Journal of Sulfur Chemistry \\
\hline Manuscript ID: & Draft \\
\hline Manuscript Type: & Research Article \\
\hline Date Submitted by the & $\mathrm{n} / \mathrm{a}$ \\
\hline Complete List of Authors: & $\begin{array}{l}\text { Smith, K; Cardiff University, School of Chemistry } \\
\text { El-Hiti, Gamal; Cardiff University, School of Chemistry } \\
\text { Al-zuhairi, Ali; Cardiff University, School of Chemistry }\end{array}$ \\
\hline Keywords: & $\begin{array}{l}\text { polymeric sulfides, polycondensation, dihaloalkanes, sodium sulfide, } \\
\text { synthesis }\end{array}$ \\
\hline
\end{tabular}

\title{
SCHOLARONE
}

Manuscripts 


\section{The synthesis of polymeric sulfides by reaction of dihaloalkanes with sodium sulfide}

Keith Smith*, Gamal A. El-Hiti and Ali J. Al-Zuhairi

School of Chemistry, Cardiff University, Main Building, Park Place, Cardiff CF10 3AT, UK

A general, simple and convenient procedure has been developed for the synthesis of various poly(alkylene sulfide)s in excellent yields from reactions of $\alpha, \omega$-dihaloalkanes with sodium sulfide nonahydrate under reflux conditions.

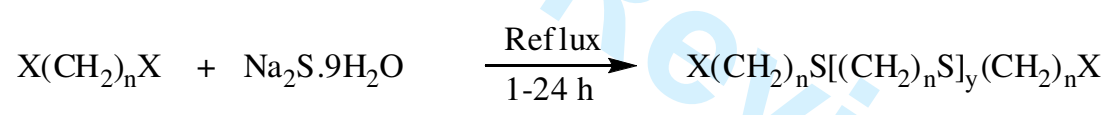

$\mathrm{X}=\mathrm{Br}, \mathrm{Cl} ; \mathrm{n}=1-10 ; \mathrm{y}=1-42$ 


\title{
The synthesis of polymeric sulfides by reaction of dihaloalkanes with sodium sulfide
}

\author{
Keith Smith*, Gamal A. El-Hiti ${ }^{\dagger}$ and Ali J. Al-Zuhairi \\ School of Chemistry, Cardiff University, Main Building, Park Place, Cardiff CF10 3AT, UK
}


Abstract: Several poly(alkylene sulfide)s have been synthesized in excellent yields from reactions of $\alpha, \omega$-dibromo- and/or $\alpha, \omega$-dichloroalkanes with sodium sulfide nonahydrate under reflux conditions. The procedure is general, simple and convenient for the production of various poly(alkylene sulfide)s and the way reaction parameters influence the properties of the polymers formed has been examined.

Keywords: polymeric sulfides; polycondensation; dihaloalkanes; sodium sulfide; synthesis

\section{Introduction}

Poly(alkylene sulfide)s are important polymers and their applications have been reviewed recently (1). They possess excellent thermal stability, weatherability, solvent resistance and oil resistance (2-4) and hence are widely used in coatings, adhesives, sealants, insulators and other applications (5-8). Also, poly(alkylene sulfide)s find application in vulcanizing rubbers (9). Moreover, poly(alkylene sulfide)- $\mathrm{AgNO}_{3}$ electrolytes show interesting conductivities (10). Therefore, the syntheses of such polymers are always of interest.

Poly(alkylene sulfide)s are usually prepared by one of four major methods: polymerization of episulfides; reactions of dithiols with carbonyl compounds; addition of dithiols to diolefins; and reactions of dithiols with dihalides. The first two obviously apply to only very specific types of polymeric sulfides (containing a two-carbon or one-carbon spacer group respectively), while the other two methods are not simple to operate and require the availability of appropriate dithiols. Other problems may also arise. For example, in the episulfide polymerization, the presence of disulfide impurities results in poor control over molecular weight distribution; therefore, work carried out by Wang and Tirelli (11) was aimed at minimizing the presence of disulfides and optimizing synthesis procedures.

In view of the above problems and also on grounds of convenience and cheapness, a method involving direct reaction of a metal sulfide with a dihaloalkane would have obvious attractions. Early workers prepared poly(alkylene sulfide)s from dihaloalkanes and potassium sulfide; however, they used only 1,2-dihaloethenes and the polymeric materials obtained were poorly characterized (12). Later, reaction of dichloromethane (DCM) with sodium sulfide nonahydrate was shown to form tetrathiocane first, but treatment of this with $\mathrm{BF}_{3}$ gave poly(methylene sulfide), which was obtained as an insoluble polymer (13). In 1974, Landini and Rolla (14) demonstrated that excellent yields of simple dialkyl sulfides can be obtained from sodium sulfide and monohaloalkanes using a phase-transfer catalysis 


\section{K. Smith et al.}

technique. Related reactions of sodium dithiolates with their corresponding dihalides gave polymers, with some cyclic oligomers also formed (15), and Imai and Ueda (16) reported that a phase transfer catalyst could be used to assist in the synthesis of such poly(alkylene sulfide)s. Subsequently, the same group reported the preparation of higher molecular weight poly(alkylene sulfide)s from dibromoalkanes having relatively long spacer groups (8-11 carbon atoms) by reaction with $1 \mathrm{M}$ aqueous sodium sulfide solution in the presence of quaternary ammonium or phosphonium salts $(4 \mathrm{~mol} \%)$ under a nitrogen atmosphere at $100^{\circ} \mathrm{C}$ for $24 \mathrm{~h}$ (17). The yields of polymers were good (86-99\% depending on the type of catalyst used). However, application of the process on only a small scale (1-2 g) and with a restricted range of dibromoalkanes, together with the need for a catalyst, a long reaction time and use of an inert atmosphere, limit the attractiveness of the process; also the factors that influence the process are not clear.

As a part of our own interest in the synthesis of sulfur-containing compounds (18) we have examined the reaction of dibromoalkanes and dichloroalkanes with sodium sulfide in more detail. We have been able to produce a range of polymers simply from reactions of dihaloalkanes with cheap sodium sulfide nonahydrate by use of reflux conditions in the absence of a catalyst or additional solvent. The process has been applied to dihaloalkanes with spacer lengths from 1 to 10 carbons and generally gives excellent yields. In this paper we report the high yielding syntheses of a range of such poly(alkylene sulfide)s. Very recently, we have synthesized a range of borane adducts derived from such polymeric sulfides as new hydroborating and reducing reagents, which might well be suitable for large scale industrial application (19).

\section{Results and Discussion}

Initial experiments were conducted in which mixtures of dibromomethane and various quantities of sodium sulfide nonahydrate (1.0-1.5 mole equivalents) were heated under reflux for various times with efficient stirring (Scheme $1 ; n=1$ ). The mixtures became very viscous and on cooling to room temperature produced solids, which were filtered, washed with water and dried to give the polymeric material $\mathbf{1}$ in high yield. The yield of $\mathbf{1}$ was $95 \%$ when the reaction time was $4 \mathrm{~h}$ and the molar ratio of $\mathrm{Na}_{2} \mathrm{~S}_{2} 9 \mathrm{H}_{2} \mathrm{O}$ to dibromomethane was 1.5:1.

The solubility of polymeric material $\mathbf{1}$ was poor in organic solvents and we were unable to run the ${ }^{1} \mathrm{H}$ NMR spectrum or gel permeation chromatography (GPC) analysis for such material. Therefore, our attention was next turned to investigation of the synthesis of 
other polymeric materials in which various $\alpha, \omega$-dibromoalkanes having different spacer group chain lengths from 2 to 10 carbons were used (Scheme 1). The molar ratio of $\mathrm{Na}_{2} \mathrm{~S} .9 \mathrm{H}_{2} \mathrm{O}$ :dibromoalkane was kept at 1.5:1 but the reaction time was varied for each dibromoalkane in order to provide high yields of polymeric material. Table 1 gives the reaction times, yields, melting points, average molecular weights calculated by GPC and the average number of repeating units calculated from the ${ }^{1} \mathrm{H}$ NMR spectrum for poly(alkylene sulfide)s 1-10. No NMR spectroscopy or GPC analysis was carried out for 2 since that material, like 1, was highly insoluble in organic solvents.

\section{Scheme 1 here}

The average molecular weights calculated by GPC were usually higher than those calculated based on the number of repeating units calculated from the ratio of end groups $\mathrm{CH}_{2} \mathrm{Br}$ to internal $\mathrm{CH}_{2} \mathrm{SCH}_{2}$ units in the ${ }^{1} \mathrm{H}$ NMR spectra. In some cases this may be because of the presence of significant quantities of disulfide impurities, which lead to additional NMR signals that are not taken account of in the calculations. Another factor may be because polystyrene was used as the GPC standard rather than a polymeric sulfide. However, the trends in molecular weights derived from GPC analysis were consistent with the trends in the number of repeating units calculated based on ${ }^{1} \mathrm{H}$ NMR spectra.

Table 1 here

As can be seen from Table 1, the reaction is simple, general, accommodates various spacer chain lengths varying from 1 to 10 and usually provides high yields (90-100\%) of the polymeric sulfides. The reaction involves no solvent and employs inexpensive starting materials. This therefore represents a very useful general method for the synthesis of poly(alkylene sulfide)s.

However, the yield of polymeric sulfide 4 was very low (11\%) under the conditions tried. In this case tetrahydrothiophene (11; Figure 1) was obtained in $78 \%$ yield due to rapid cyclization on reaction of 1,4-dibromobutane with sodium sulfide. No attempts were made to try to find conditions under which the yield of $\mathbf{4}$ could be increased. It has been reported previously that reaction of 1,4-dibromobutane in chloroform with sodium sulfide nonahydrate in water in the presence of a phase transfer catalyst under nitrogen gave $\mathbf{1 1}$ in $42 \%$ yield, but no polymeric material of the structure 4 was reported in that case (20). In contrast, 


\section{K. Smith et al.}

1,2-dithiane (12) was produced in $80 \%$ yield from the reaction of 1,4-dibromobutane with sodium sulfide in the presence of sulfur and didecyldimethylammonium bromide, as a phase transfer catalyst, at $30^{\circ} \mathrm{C}$ for $4 \mathrm{~h}$ in a mixture of water and chloroform (21). In our current reaction the preferential formation of $\mathbf{1 1}$ accounts for the low yield of $\mathbf{4}$. No evidence was found to suggest the formation of a significant amount of $\mathbf{1 2}$ during the reaction.

Figure 1 here

The NMR spectra of polymeric sulfides 8-10 $(n=8-10)$ showed the prevalence of short chain polymers in which the calculated average numbers of repeating units were in the range 3-5, compared with averages of 24-43 repeating units in cases where $n$ was less than 8 . We therefore varied the reaction time and the quantity of sodium sulfide in an attempt to increase the chain length of polymeric sulfide $\mathbf{8}$ and to see what effect these parameters have on the chain length and physical properties (e.g. melting point) of the polymer. Initially, the reaction of 1,8-dibromooctane (1 mole equivalent) with sodium sulfide nonahydrate (1.5 mole equivalents) was conducted under reflux conditions and the reaction time was varied (2-24 h). The results obtained are recorded in Table 2.

Table 2 here

The results (Table 2) show that the chain length (y) increases with increasing reaction time up to a reaction period of around $16 \mathrm{~h}$, by which time the average number of repeating units (y) was ca. 20. Also, the yield and melting point of polymeric material 8 increased in line with the chain length as the reaction period increased. The reaction conducted for the shortest period $(2 \mathrm{~h})$ produced a low yield $(30 \%)$ of material that contained a calculated average of only two sulfur atoms per molecule $(y=1$, Scheme 1$)$. It is likely that low crosssolubility of water with both the longer chain dibromides and with the corresponding intermediate thiolates is responsible for the longer time taken in these cases for the polymer chain length to reach the higher values.

We also investigated reactions of 1,8-dibromooctane with various quantities of sodium sulfide (1.0-2.5 mole equivalents) under reflux conditions for a fixed period of $5 \mathrm{~h}$ and the results obtained are shown in Table 3. 
Increasing the quantity of sodium sulfide resulted in a longer chain length over the fixed $5 \mathrm{~h}$ reaction period, but there were still only $c a .8$ repeating units when 2.5 mole equivalents of sodium sulfide were used. Also, use of 1.2 mole equivalents for a longer period (24 h) provided polymeric sulfide 8 with only ca. 6 repeating units. Clearly, at least 1.5 mole equivalents of sodium sulfide and a prolonged reaction time are important for obtaining a longer chain polymer.

Attention was next turned to use of various dichloroalkanes with sodium sulfide nonahydrate to produce the polymeric sulfides 13-17 (Scheme 2). These reactions were significantly slower than those using dibromides and therefore required longer reaction times to provide good yields of polymers. In the early experiments, the NMR peaks assumed to arise from disulfides were more prominent in the products than had been observed with the dibromides. In the case of reaction of 1,6-dichlorohexane with sodium sulfide nonahydrate (1.5 mole equivalents) for $48 \mathrm{~h}$ the product mixture was treated with methanol and most of the polymeric material (16) precipitated and was collected by filtration. The filtrate was then cooled to $0{ }^{\circ} \mathrm{C}$ and more 16 separated out. The total yield of $\mathbf{1 6}$ was around $60 \%$. The filtrate was then concentrated under reduced pressure to give a $40 \%$ yield of material that was mainly the cyclic disulfide 1,2-dithiocane (18; Figure 2), identical in all respects with authentic material produced from oxidation of 1,6-hexanedithiol with bromine (22). It is believed that compound $\mathbf{1 8}$ resulted from oxidation in air of 1,6-hexanedithiol formed in-situ from 1,6-dichlorohexane under the conditions used.

Figure 2 here

The yield of $\mathbf{1 6}$ was higher when the quantity of sodium sulfide nonahydrate was increased to 2.5 mole equivalents, but 18 was still evident in the ${ }^{1} \mathrm{H}$ NMR spectrum of the product mixture, albeit in low proportion. Several attempts were made in order to find conditions under which 18 could be eliminated. However, carrying out the reaction under an inert atmosphere or use of $\mathrm{KI}$ as a catalyst for the nucleophilic substitution reaction had little effect on the yield of $\mathbf{1 6}$ or the proportion of $\mathbf{1 8}$ formed. In the course of these investigations, it was noticed that volatile material, believed to contain 1,6-hexanedithiol, evaporated from the reaction mixture and after condensation ran down the wall of the flask rather than 


\section{K. Smith et al.}

dripping back directly into the reaction mixture. It was felt that the liquid dithiol might be reevaporating on contact with the hot walls of the flask before it got back into the reaction mixture, thereby preventing its reaction with further chloroalkyl-terminated polymer in the flask and also increasing the likelihood of its oxidation to 18. In order to minimize this problem, a condenser with a long drip-tip, which would allow the condensed material back into the reaction mixture more efficiently, was employed. Use of such a condenser improved the yield of $\mathbf{1 6}$ and also reduced the amount of $\mathbf{1 8}$ to a trace. Such a condenser was therefore used for further investigations.

A series of experiments was conducted in which the conditions of the reaction were varied in an attempt to produce the corresponding polymeric sulfides 13-17 in high yields. The optimum yields were obtained when a larger quantity of sodium sulfide nonahydrate (2.5 mole equivalents) was used for a longer reaction time (8-24 h, Table 4) than was the case for the corresponding dibromoalkanes (1-6 h). The NMR spectra of 14-17 showed the presence of only very low proportions of peaks thought to be due to disulfides.

\section{Scheme 2 here}

Table 4 here

As can be seen from Table 4, the reaction is general and usually provides high yields of the polymeric sulfides. However, the reactions were slower than those involving use of dibromoalkanes (Table 1) and gave shorter chain length polymers. Again, the yield of polymeric sulfide 14 was low (19\%) due to formation of tetrahydrothiophene (11; Figure 1) in high yield $(75 \%)$. It is clear that poly(alkylene sulfide)s can generally be synthesized efficiently in high yields from either dibromo- or dichloroalkanes by reactions with sodium sulfide. However, longer reaction times and/or greater quantities of sodium sulfide are required with dichloroalkanes in order to achieve comparable chain lengths.

For the polymers with the very short spacer groups (one or two methylene units) there was an issue of lack of solubility of the polymers produced under all of the conditions tried. Several attempts were therefore made to synthesize a soluble polymeric material of structure similar to $\mathbf{2}$ or $\mathbf{1 3}$ to widen the scope of application for such polymeric materials. It was thought that the low solubility might be caused by longer chain lengths and that shorter chain lengths could be encouraged by the addition of a monohaloalkane to terminate the polymeric chains. Therefore, mixtures of 1,2-dichloroethane ( 0.6 mole equivalents), a haloalkane 
(1-bromobutane, 2-bromopropane, 1-chlorobutane or 2-chlorobutane; 0.4 mole equivalents) and sodium sulfide nonahydrate (1.5 mole equivalents) were refluxed for $12 \mathrm{~h}$ (Scheme 3 ). The polymeric materials produced (19-22) were treated with dichloromethane (DCM) and the residual solids (longer chain polymers) were removed by filtration. The DCM was removed under reduced pressure from the filtrate to give the shorter chain polymers as white solids. The total yield of the polymeric materials 19-22 are shown in Figure 3. The ${ }^{1} \mathrm{H}$ NMR spectra of the shorter chain polymers indicated that the numbers of repeating units (y) were in the range of 3-8. The low solubility of the residual solid polymers meant that it was difficult to obtain molecular weight data, but it is assumed that the average chain lengths of such materials were significantly greater.

\section{Scheme 3 here}

Figure 3 here

It is clear from Figure 3 that the total yields of polymeric materials 19-22 were high. In general the yields of the short chain polymeric materials using monobromoalkanes to terminate the chains were higher than those obtained with monochloroalkanes. Alkyl bromides tend to terminate the polymerization reaction faster than alkyl chlorides and as a result the proportions of short chain oligomers are higher and the average chain lengths of such oligomers are lower ( $y=3-5$ with the bromides compared to $y=5-8$ with the chlorides). Also, the yield of short chain polymeric materials using 1-bromobutane was higher than that obtained with 2-bromopropane (Figure 3). This arises because the rate of nucleophilic substitution of primary alkyl halides is higher than that of secondary ones in these reactions (23).

The melting points of the short chain polymeric materials prepared using primary alkyl halides were in the range of $70-72^{\circ} \mathrm{C}$, while, the melting points of the corresponding ones obtained with secondary alkyl halides were a bit lower $\left(64-68^{\circ} \mathrm{C}\right)$.

\section{Conclusions}

A general method for the synthesis of symmetrical poly(alkylene sulfide)s has been developed based on reactions of $\alpha, \omega$-dihaloalkanes of different spacer lengths with cheap sodium sulfide nonahydrate, in the absence of any added solvent, base or catalyst. The 
process is simple, general, and convenient and provides excellent yields of polymer sulfides. Dibromoalkanes react faster than dichloroalkanes and under comparable conditions provide polymers with greater average chain lengths and molecular weights. The chain lengths of the polymeric materials can be increased by increasing the reaction time and/or the quantity of sodium sulfide. On the other hand, chain lengths are reduced by the addition of monohaloalkanes. Consequently, the properties of the polymeric materials obtained can be controlled to a large extent by judicious choice of dihaloalkane, haloalkane terminating agent (if any), reactant proportions, and reaction time.

\section{Experimental}

\subsection{General}

Melting point determinations were performed by the open capillary method using a Gallenkamp melting point apparatus and are reported uncorrected. ${ }^{1} \mathrm{H}$ and ${ }^{13} \mathrm{C}$ NMR spectra were recorded on a Bruker AV500 spectrometer operating at $500 \mathrm{MHz}$ for ${ }^{1} \mathrm{H}$ and $125 \mathrm{MHz}$ for ${ }^{13} \mathrm{C}$ measurements. Chemical shifts are reported relative to TMS and coupling constants $J$ are in $\mathrm{Hz}$ and have been rounded to the nearest whole number. Assignments of signals are based on coupling patterns and expected chemical shift values and have not been rigorously confirmed. Signals with similar characteristics might be interchanged. Gel permeation chromatography (GPC) was carried out using a GPC MAX variable loop equipped with two KF-805L SHODEX columns in $\mathrm{CHCl}_{3}$, with a RI (VE3580) detector using a GPC MAX pump operating at flow rate of $1 \mathrm{ml} / \mathrm{min}$. Calibration was achieved using a series of Viscotek polystyrene standards up to $\mathrm{Mw}=9.4 \times 10^{5}$. Microanalyses were performed by Warwick analytical service at the University of Warwick. Chemicals were obtained from Aldrich Chemical Company and used without further purification.

\subsection{Typical experimental procedure for the synthesis of polymeric sulfides 1-10}

Dibromoalkane $(0.10 \mathrm{~mol})$ and sodium sulfide nonahydrate $(36.0 \mathrm{~g}, 0.15 \mathrm{~mol})$ were placed in a 1 liter round bottom flask that that contained a magnetic bar. The flask was equipped with a water condenser and placed in an oil bath set at $140-160^{\circ} \mathrm{C}$. The mixture was heated under reflux for 1-6 h with vigorous stirring, by which time a very viscous material resulted. Water $(c a .30 \mathrm{ml})$ was added to the hot reaction mixture, which was then poured into a clean beaker and vigorously stirred before being left to cool to room temperature. The solid mass was then collected by filtration, washed thoroughly with water $(3 \times 10 \mathrm{ml})$ and dried at $50^{\circ} \mathrm{C}$ under 
reduced pressure to give a white powdery solid. The physical properties and NMR spectroscopic data of 1-10 are represented in Tables 1 and 5, respectively.

\subsection{Typical experimental procedure for the synthesis of polymeric sulfides 13-17}

The procedure was similar to that described for the formation of polymers 1-10 but using a mixture of dichloroalkane $(0.10 \mathrm{~mol})$ and sodium sulfide nonahydrate $(60.0 \mathrm{~g}, 0.25 \mathrm{~mol})$ heated under reflux for $8-24 \mathrm{~h}$ in a bath set at $140-160^{\circ} \mathrm{C}$. Also, a condenser with a long drip-tip was used to minimize disulfide formation. The physical properties and NMR spectroscopic data of 13-17 are represented in Tables 4 and 5, respectively.

\subsection{Typical experimental procedure for the synthesis of short chain polymeric sulfides $18-21$}

A mixture 1,2-dichloroethane $(5.8 \mathrm{~g}, 60 \mathrm{mmole})$, haloalkane (40 mmol) and sodium sulfide nonahydrate $(36.0 \mathrm{~g}, 150 \mathrm{mmol})$ was heated under reflux with efficient stirring for $12 \mathrm{~h}$ in a silicon oil bath set at $140-160^{\circ} \mathrm{C}$. The reaction mixture was allowed to cool and then water (30 ml) was added. The solid was removed by filtration and washed thoroughly with water (3 x $30 \mathrm{ml}$ ) and dried to give a white solid. The solid was treated with DCM (30 ml) and the insoluble solid was removed by filtration to give the longer chain polymers. The DCM was removed under reduced pressure from the filtrate to give the shorter chain polymers as white solids. The NMR spectroscopic data of the short chain polymers 19-22 are represented in Table 5.

Table 5 here

\subsection{Tetrahydrothiophene (11)}

A mixture of 1,4-dibromobutane or 1,4-dichlorobutane $(0.10 \mathrm{mmol})$ and sodium sulfide nonahydrate $(1.5-2.5 \mathrm{mmol})$ was heated under reflux for 6-24 $\mathrm{h}$. The mixture was cooled and dichloromethane $(50 \mathrm{ml})$ was added. The layers were separated and the organic layer was dried $\left(\mathrm{MgSO}_{4}\right)$ and concentrated under reduced pressure. Diethyl ether $(30 \mathrm{ml})$ was added to precipitate the polymeric material $\mathbf{4}$ or $\mathbf{1 4}$. The solid was filtered and washed with diethyl ether $(30 \mathrm{ml})$. The filtrates were combined and the solvent was removed under reduced pressure to give tetrahydrothiophene (11) in $75-78 \%$ yield. ${ }^{1} \mathrm{H}$ NMR $\left(500 \mathrm{MHz}, \mathrm{CDCl}_{3}\right), \delta$ (ppm): 2.76 (t, $\left.J=6 \mathrm{~Hz}, 4 \mathrm{H}, \mathrm{CH}_{2} \mathrm{~S}\right), 1.87$ (t, $\left.J=6 \mathrm{~Hz}, 4 \mathrm{H}, \mathrm{CH}_{2} \mathrm{CH}_{2} \mathrm{~S}\right):{ }^{13} \mathrm{C}$ NMR $(125 \mathrm{MHz}$, 
K. Smith et al.

$\left.\mathrm{CDCl}_{3}\right), \delta$ (ppm): $31.8\left(\mathrm{CH}_{2} \mathrm{~S}\right), 31.0\left(\mathrm{CH}_{2} \mathrm{CH}_{2} \mathrm{~S}\right)$; EI-MS $(\mathrm{m} / \mathrm{z}, \%): 88\left(\mathrm{M}^{+}, 88\right), 60\left([\mathrm{M}-\mathrm{S}]^{+}\right.$, 100); HRMS (EI): calcd for $\mathrm{C}_{4} \mathrm{H}_{8} \mathrm{~S}$ (M), 88.0347; found, 88.0343.

\subsection{1,2-Dithiocane (18)}

Compound 18 was produced in around $40 \%$ yield as a side product from reaction of 1,6-dichlorohexane with sodium sulfide nonahydrate along with polymeric material 16. Also, it was produced in $87 \%$ yield by oxidation of 1,6-hexanedithiol with bromine according to the literature procedure (22). ${ }^{1} \mathrm{H}$ NMR (500 MHz, $\left.\mathrm{CDCl}_{3}\right), \delta(\mathrm{ppm}): 3.35(\mathrm{t}, J=7 \mathrm{~Hz}, 4 \mathrm{H}$, $\mathrm{CH}_{2} \mathrm{SS}$ ), 1.65 (m, $\left.4 \mathrm{H}, \mathrm{CH}_{2} \mathrm{CH}_{2} \mathrm{SS}\right), 1.30$ (m, $\left.4 \mathrm{H}, \mathrm{CH}_{2} \mathrm{CH}_{2} \mathrm{CH}_{2} \mathrm{SS}\right):{ }^{13} \mathrm{C} \mathrm{NMR}(125 \mathrm{MHz}$, $\left.\mathrm{CDCl}_{3}\right), \delta$ (ppm): $38.9\left(\mathrm{CH}_{2} \mathrm{SS}\right), 29.1$ (t, $\left.\mathrm{CH}_{2} \mathrm{CH}_{2} \mathrm{SS}\right), 27.5\left(\mathrm{CH}_{2} \mathrm{CH}_{2} \mathrm{CH}_{2} \mathrm{SS}\right)$; EI-MS $(\mathrm{m} / z$, \%): $148\left(\mathrm{M}^{+}, 37\right), 116\left([\mathrm{M}-\mathrm{S}]^{+}, 25\right), 101(20), 87(100), 84\left([\mathrm{M}-2 \mathrm{~S}]^{+}, 25\right)$; HRMS (EI): calcd for $\mathrm{C}_{6} \mathrm{H}_{12} \mathrm{~S}_{2}(\mathrm{M}), 148.0380$; found, 148.0376 .

\section{Acknowledgements}

We thank the Iraqi Government and Cardiff University for financial support.

\section{References}

(1) Vo, C.D.; Kilcher, G.; Tirelli, N. Macromol. Rapid Commun. 2009, 30, 299-315.

(2) Ellerstein, S. In Handbook of Polymer, 3rd ed., Wiley-Interscience: New York, 1985.

(3) Lee, T.C.P. In Properties and Applications of Elastomeric Polysulfides; Dolbey, R., Ed.; Rapra Technology Ltd.: Shrewsbury, 1999; Vol. 9.

(4) Mahon, A.; Kemp, T.J.; Coates, R.J. Polym. Degrad. Stab. 1998, 62, 15-24.

(5) Lee, C. Chang, T.C.; Huang, Y.-H. US Patent, 5432257, 1995.

(6) Tobolsky, A.V. In The Chemistry of Sulfides; Wiley-Interscience: New York, 1968.

(7) Bahh, C.A.; Baah, J.I.; Gianadda, P.; Fisher, C. Mater. Des. 2000, 21, 211-215.

(8) Lucke, H. ALIPS-Aliphatic Polysulfides; Hüthig and Wepf: Basel, 1994.

(9) Fettes, E.M.; Jorczak, J.S.; Panek, J.R. Ind. Eng. Chem. 1954, 46, 1539-1541.

(10) Clancy, S.; Shriver, D.F.; Ochrymowycz, L.A. Macromolecules 1986, 19, 606-611.

(11) Wang, L.; Kilcher, G.; Tirelli, N. Macromol. Chem. Phys. 2009, 210, 447-456.

(12) (a) Crafts, J.M. Justus Liebigs Ann. Zhem. 1862, 124, 110-114; (b) Meyer, V. Ber. Dtsch. Chem. Ges. 1886, 19, 3259-3266.

(13) Russo, M.; Mortillaro, L.; De Cecchi, C.; Valle, G.; Mammi, M. J. Polym. Lett. Ed. 1965, 3, 501-504. 
(14) Landini, D.; Rolla, F. Synthesis 1974, 565-566.

(15) Montaudo, G.; Puglisi, C.; Scamporrino, E.; Vitalini, D. Macromolecules 1986, 19, 2689-2692.

(16) Imai, Y.; Kato, A.; Ii, M., Ueda, M. J. Polym. Sci., Polym. Lett. Ed. 1979, 17, 579583.

(17) Ueda, M.; Oishi, Y.; Sakai, N. Macromolecules 1982, 15, 248-251.

(18) See for example: (a) Metwally, M.A.; Khalifa M.E.; El-Hiti, G.A. J. Sulfur Chem. 2010, 31, 205-229; (b) Smith, K.; Barratt, M.L. J. Org. Chem. 2007, 72, 1031-1034; (c) Smith, K.; El-Hiti, G.A.; Hegazy, A.S. J. Sulfur Chem. 2005, 26, 121-131; (d) Smith, K.; El-Hiti, G.A.; Mahgoub, S.A. Synthesis 2003, 2345-2348; (e) El-Hiti, G.A. Sulfur Reports, 2001, 22, 217-250; (f) Smith, K.; Tzimas, M.; Brown, C.M.; Payne, K. Sulfur Lett. 1999, 22, 89-101; (g) Smith, K.; Tzimas, M.; Brown, C.M.; Payne, K. Sulfur Lett. 1999, 22, 103-123; (h) Smith, K.; Shukla A.P.; Matthews, I. Sulfur Lett. 1996, 20, 121-137; (i) Smith, K.; Hou, D. J. Org. Chem. 1996, 61, 1530-1532; (j) Smith, K.; Anderson, D.; Matthews, I. J. Org. Chem. 1996, 61, 662-665; (k) AbdelMegeed, M.F.; Aly, Y.L.; Saleh, M.A.; Abdo, I.M.; El-Hiti, G.A.; Smith, K. Sulfur Lett. 1995, 19, 129-140; (1) Smith, K.; Tzimas, M. J. Chem. Soc., Perkin Trans. 1 1995, 2381-2382; (m) Smith, K.; Anderson, D.; Matthews, I. Sulfur Lett. 1995, 18, 79-95; (n) Smith, K.; Lindsay, C.M.; Morris, I.K.; Matthews, I.; Pritchard, G.J. Sulfur Lett. 1994, 17, 197-216.

(19) Smith, K.; Balakit, A.A.; Pardasani, R.T.; El-Hiti, G.A. J. Sulfur Chem. 2011, 32, in press; doi: 10.1080/17415993.2011.590489.

(20) Sundarrajan, S.; Srinivasan K.S.V. Macromol. Rapid Commun. 2004, 25, 1406-1409.

(21) Sonavane, S.U.; Chidambaram, M.; Khalil, S.; Almog, J.; Sasson, Y. Tetrahedron Lett. 2008, 49, 520-522.

(22) Ali, M.; McDermott, M. Tetrahedron Lett. 2002, 43, 6271-6273.

(23) Clayden, J.; Greeves, N.; Warren, S.; Wothers, P. In Organic Chemistry, Oxford University Press: Oxford, UK, 2001. 
K. Smith et al.

$$
\begin{array}{r}
\mathrm{Br}\left(\mathrm{CH}_{2}\right)_{\mathrm{n}} \mathrm{Br}+\mathrm{Na}_{2} \mathrm{~S} .9 \mathrm{H}_{2} \mathrm{O} \underset{1-6 \mathrm{~h}}{\stackrel{\text { Reflux }}{\longrightarrow}} \mathrm{Br}\left(\mathrm{CH}_{2}\right)_{\mathrm{n}} \mathrm{S}\left[\left(\mathrm{CH}_{2}\right)_{\mathrm{n}} \mathrm{S}\right]_{\mathrm{y}}\left(\mathrm{CH}_{2}\right)_{\mathrm{n}} \mathrm{Br} \\
\mathrm{n}=1-10 ; \mathrm{y}=3-42
\end{array}
$$

Scheme 1. Synthesis of poly(alkylene sulfide)s 1-10 from polycondensation of dibromoalkanes with $\mathrm{Na}_{2} \mathrm{~S} .9 \mathrm{H}_{2} \mathrm{O}$. 


$$
\begin{gathered}
\mathrm{Cl}\left(\mathrm{CH}_{2}\right)_{\mathrm{n}} \mathrm{Cl}+\mathrm{Na}_{2} \mathrm{~S} .9 \mathrm{H}_{2} \mathrm{O} \quad \stackrel{\text { Reflux }}{\text { 8-24h }} \mathrm{Cl}\left(\mathrm{CH}_{2}\right)_{\mathrm{n}} \mathrm{S}\left[\left(\mathrm{CH}_{2}\right) \mathrm{nS}\right]_{\mathrm{y}}\left(\mathrm{CH}_{2}\right)_{\mathrm{n}} \mathrm{Cl} \\
\mathrm{n}=2,4,5,6 \text { and } 8 ; \mathrm{y}=2-23
\end{gathered}
$$

Scheme 2. Synthesis of poly(alkylene sulfide)s 13-17 from polycondensation of dichloroalkanes and $\mathrm{Na}_{2} \mathrm{~S} .9 \mathrm{H}_{2} \mathrm{O}$. 
K. Smith et al.

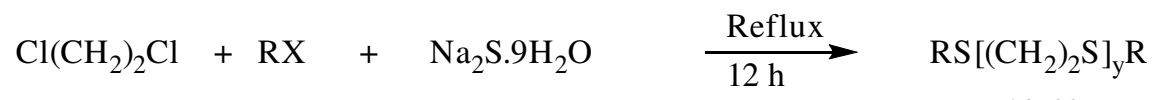

$$
\begin{aligned}
& \mathrm{R}=n-\mathrm{Bu}, \text { iso }-\mathrm{Bu}, \text { iso }-\mathrm{Pr} ; \mathrm{X}=\mathrm{Br}, \mathrm{Cl} \\
& \text { 19-22 }
\end{aligned}
$$

Scheme 3. Synthesis of poly(alkylene sulfide)s 19-22 from polycondensation of 1,2-dichloroethane and $\mathrm{Na}_{2} \mathrm{~S} .9 \mathrm{H}_{2} \mathrm{O}$ in the presence of haloalkanes. 
<smiles>C1CCSC1</smiles>

11

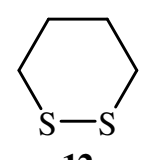

12

Figure 1. Structures of tetrahydrothiophene (11) and 1,2-dithiane (12) 
$K$. Smith et al.

Figure 2. Structure of 1,2-dithiocane (18) 


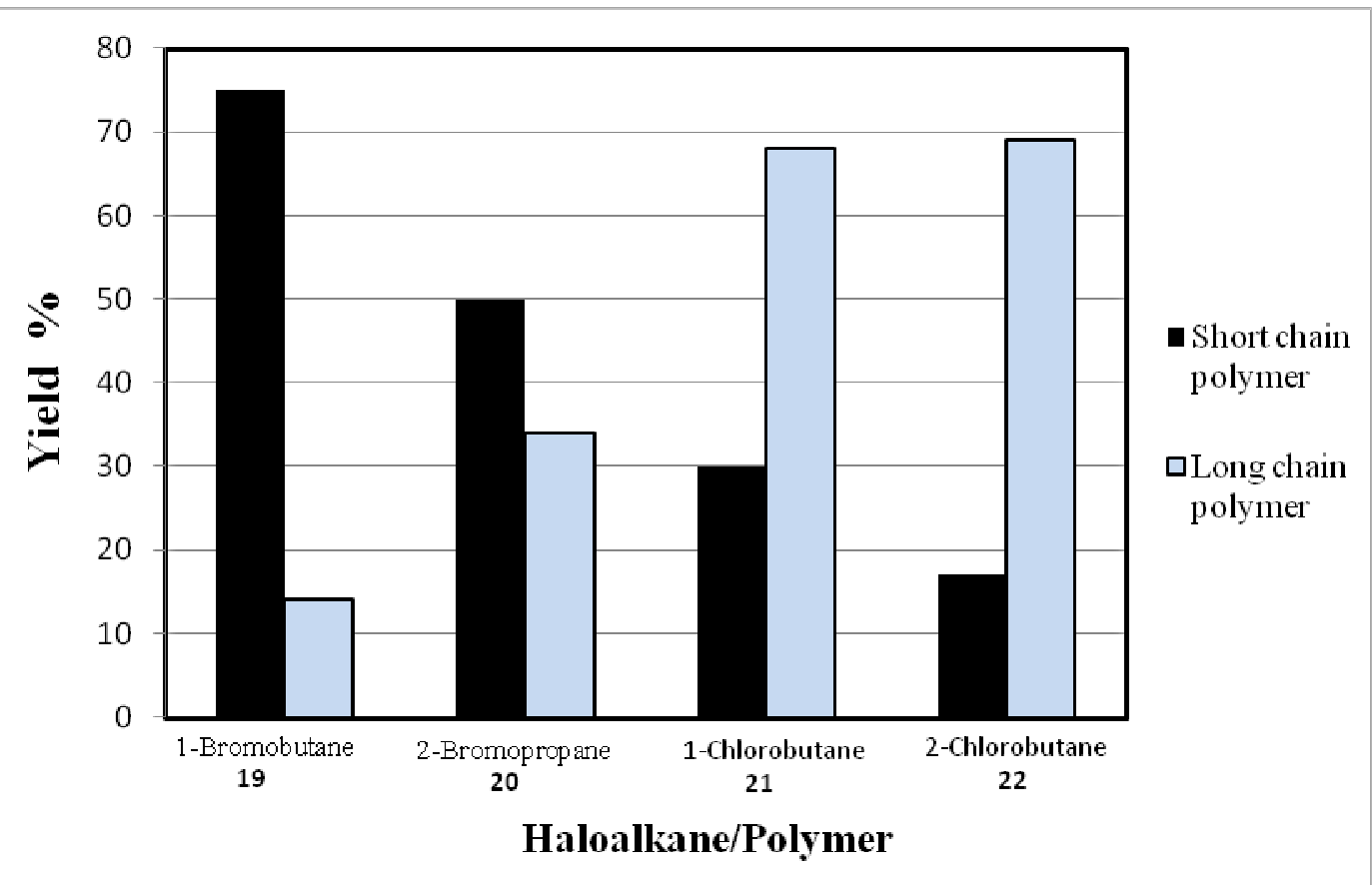

Figure 3. Total yields of polymeric materials 19-22 obtained from polycondensation of 1,2-dichloroethane and $\mathrm{Na}_{2} \mathrm{~S} .9 \mathrm{H}_{2} \mathrm{O}$ in the presence of haloalkanes under reflux conditions. 
K. Smith et al.

Table 1. Synthesis of poly(alkylene sulfide)s 1-10 from reactions of 1,n-dibromoalkanes and sodium sulfide nonahydrate according to Scheme $1 .{ }^{a}$

\begin{tabular}{lcccccc}
\hline polymer & $\mathrm{n}$ & Time $(\mathrm{h})$ & M.P. $\left({ }^{\circ} \mathrm{C}\right)$ & Yield $(\%)^{\mathrm{b}}$ & $\mathrm{Mn}^{\mathrm{c}}$ & $\begin{array}{c}\text { Approximate number of } \\
\text { repeating units }(\mathrm{y})^{\mathrm{d}}\end{array}$ \\
\hline $\mathbf{1}^{\mathrm{e}}$ & 1 & 4 & $225-230$ & 95 & not known & not known \\
$\mathbf{2}^{\mathrm{e}}$ & 2 & 1 & $185-186$ & 100 & not known & not known \\
$\mathbf{3}$ & 3 & 4 & $55-57$ & 100 & 4546 & 24 \\
$\mathbf{4}$ & 4 & 6 & $65-68$ & $15^{\mathrm{f}}$ & 5939 & 43 \\
$\mathbf{5}$ & 5 & 4 & $70-75$ & 94 & 3921 & 33 \\
$\mathbf{6}$ & 6 & 4 & $70-77$ & 100 & 4068 & 33 \\
$\mathbf{7}$ & 7 & 5 & $78-85$ & 90 & 4308 & 33 \\
$\mathbf{8}$ & 8 & 5 & $58-64$ & 97 & 1201 & 5 \\
$\mathbf{9}$ & 9 & 5 & $70-76$ & 92 & 2082 & 5 \\
$\mathbf{1 0}$ & 10 & 5 & $70-78$ & 95 & 1700 & \\
\hline
\end{tabular}

Notes: ${ }^{\mathrm{a}}$ A mixture of dibromoalkane $(0.10 \mathrm{mmol})$ and $\mathrm{Na}_{2} \mathrm{~S} .9 \mathrm{H}_{2} \mathrm{O}(36.0 \mathrm{~g}, 0.15 \mathrm{mmol})$ was heated under reflux in an oil bath set at $140-160^{\circ} \mathrm{C}$ for the indicated reaction time.

${ }^{b}$ Yield based on an assumed empirical formula for the product of $\left(\mathrm{CH}_{2}\right)_{\mathrm{n}} \mathrm{S}$.

${ }^{c}$ The average molecular weight calculated by GPC.

${ }^{\mathrm{d}}$ Calculated from the ${ }^{1} \mathrm{H}$ NMR spectrum by comparison of the integrations of the $\mathrm{CH}_{2} \mathrm{Br}$ and $\mathrm{CH}_{2} \mathrm{SCH}_{2}$ signals.

e The polymeric material was highly insoluble in solvents.

${ }^{\mathrm{f}}$ Tetrahydrothiophene (11; Figure 1) was produced in $78 \%$ yield. 
Table 2. Effect of reaction time on chain length of $\mathbf{8}$ according to Scheme 1. ${ }^{\mathrm{a}}$

\begin{tabular}{lccc}
\hline Time $(\mathrm{h})$ & M.P. $\left({ }^{\circ} \mathrm{C}\right)$ & Yield $(\%)^{\mathrm{b}}$ & Approximate number of repeating units $(\mathrm{y})^{\mathrm{c}}$ \\
\hline 2 & slurry & 30 & 1 \\
5 & $58-64$ & 97 & 3 \\
8 & $80-85$ & 96 & 13 \\
16 & $110-118$ & 100 & 20 \\
24 & $110-118$ & 100 & 20 \\
\hline
\end{tabular}

Notes: ${ }^{a}$ A mixture of 1,8-dibromooctane $(27.0 \mathrm{~g}, 0.10 \mathrm{~mol})$ and $\mathrm{Na}_{2} \mathrm{~S} .9 \mathrm{H}_{2} \mathrm{O}(36.0 \mathrm{~g}, 0.15$ $\mathrm{mmol}$ ) was heated under reflux in an oil bath set at $140-160^{\circ} \mathrm{C}$ for the indicated reaction time.

${ }^{\mathrm{b}}$ Yield based on an assumed empirical formula for the product of $\left(\mathrm{CH}_{2}\right)_{\mathrm{n}} \mathrm{S}$.

${ }^{c}$ Calculated from the ${ }^{1} \mathrm{H}$ NMR spectrum by comparison of the integrations of the $\mathrm{CH}_{2} \mathrm{Br}$ and $\mathrm{CH}_{2} \mathrm{SCH}_{2}$ signals. 
K. Smith et al.

Table 3. Effect of quantities of $\mathrm{Na}_{2} \mathrm{~S} .9 \mathrm{H}_{2} \mathrm{O}$ on the average chain length of $\mathbf{8}$.

\begin{tabular}{lccc}
\hline $\mathrm{Na}_{2} \mathrm{~S} .9 \mathrm{H}_{2} \mathrm{O}$ (mol. Equiv.) & M.P. $\left({ }^{\circ} \mathrm{C}\right)$ & Yield $(\%)^{\mathrm{b}}$ & $\begin{array}{c}\text { Approximate number of repeating } \\
\text { units }(\mathrm{y})^{\mathrm{c}}\end{array}$ \\
\hline 1.0 & slurry & 25 & $1^{\mathrm{d}}$ \\
1.2 & $52-60$ & 57 & $2^{\mathrm{d}}$ \\
1.5 & $58-64$ & 97 & 3 \\
1.7 & $75-79$ & 92 & 6 \\
2.0 & $75-79$ & 92 & 6 \\
2.5 & $78-85$ & 98 & 8 \\
\hline
\end{tabular}

Notes: ${ }^{a}$ A mixture of 1,8-dibromooctane $(27.0 \mathrm{~g}, 0.10 \mathrm{mmol})$ and $\mathrm{Na}_{2} \mathrm{~S} .9 \mathrm{H}_{2} \mathrm{O}$ was heated under reflux in an oil bath set at $140-160^{\circ} \mathrm{C}$ for $5 \mathrm{~h}$.

${ }^{b}$ Yield based on an assumed empirical formula for the product of $\left(\mathrm{CH}_{2}\right)_{\mathrm{n}} \mathrm{S}$.

${ }^{c}$ Calculated from the ${ }^{1} \mathrm{H}$ NMR spectrum by comparison of the integrations of the $\mathrm{CH}_{2} \mathrm{Br}$ and $\mathrm{CH}_{2} \mathrm{SCH}_{2}$ signals.

${ }^{d}$ The number of repeating units (y) may be a little higher than reported due to the presence of a significant proportion of disulfide. 
Table 4. Synthesis of polymers $\mathbf{1 3}-\mathbf{1 7}$ from dichloroalkanes according to Scheme 2. ${ }^{\text {a }}$

\begin{tabular}{lcccccc}
\hline Polymer & $\mathrm{n}$ & Time $(\mathrm{h})$ & M.P. $\left({ }^{\circ} \mathrm{C}\right)$ & Yield $(\%)^{\mathrm{b}}$ & $\mathrm{Mn}^{\mathrm{c}}$ & $\begin{array}{c}\text { Approximate number of } \\
\text { repeating units }(\mathrm{y})^{\mathrm{d}}\end{array}$ \\
\hline $\mathbf{1 3}^{\mathrm{e}}$ & 2 & 8 & $185-186$ & 91 & not known & not known \\
$\mathbf{1 4}$ & 4 & 24 & $68-70$ & $19^{\mathrm{f}}$ & 5243 & 47 \\
$\mathbf{1 5}$ & 5 & 14 & $70-75$ & 85 & 2726 & 25 \\
$\mathbf{1 6}$ & 6 & 14 & $72-76$ & 97 & 2727 & 13 \\
$\mathbf{1 7}$ & 8 & 14 & $60-66$ & 90 & 1229 & $3^{\mathrm{g}}$ \\
\hline
\end{tabular}

Notes: ${ }^{\text {a }}$ A mixture of dichloroalkane $(0.10 \mathrm{~mol})$ and $\mathrm{Na}_{2} \mathrm{~S} .9 \mathrm{H}_{2} \mathrm{O}(60.0 \mathrm{~g}, 0.25 \mathrm{~mol})$ was heated under reflux in an oil bath set at $140-160^{\circ} \mathrm{C}$ for the indicated reaction time.

${ }^{b}$ Yield based on an assumed empirical formula for the product of $\left(\mathrm{CH}_{2}\right)_{n} \mathrm{~S}$.

${ }^{\mathrm{c}}$ The average molecular weight calculated by GPC.

${ }^{d}$ Calculated from the ${ }^{1} \mathrm{H}$ NMR spectrum by comparison of the integrations of the $\mathrm{CH}_{2} \mathrm{Br}$ and $\mathrm{CH}_{2} \mathrm{SCH}_{2}$ signals.

e The polymeric material is highly insoluble in most solvents.

${ }^{\mathrm{f}}$ Tetrahydrothiophene (11; Figure 1) was produced in $75 \%$ yield.

$\mathrm{g}$ The calculated number of repeating units is less accurate due to the presence of a significant quantity of disulfide. 
K. Smith et al.

Table 5. NMR spectra for polymeric sulfides 3-10, 14-17 and 19-22. ${ }^{a}$

\begin{tabular}{|c|c|c|}
\hline \multirow{2}{*}{ Polymer } & \multicolumn{2}{|l|}{$\operatorname{NMR}\left(\delta, \mathrm{ppm} ; \mathrm{CDCl}_{3}\right)^{\mathrm{b}}$} \\
\hline & ${ }^{1} \mathrm{H}$ NMR (500 MHz) & ${ }^{13} \mathrm{C}$ NMR $(125 \mathrm{MHz}){ }^{\mathrm{c}}$ \\
\hline 3 & $\begin{array}{l}1.90\left(\mathrm{~m}, 2 \mathrm{H}, \mathrm{CH}_{2} \mathrm{CH}_{2} \mathrm{~S}\right), 2.65(\mathrm{t}, J=7 \mathrm{~Hz}, 4 \mathrm{H}, \\
\left.\mathrm{CH}_{2} \mathrm{~S}\right), 2.80\left(\mathrm{t}, J=7 \mathrm{~Hz}, 0.166 \mathrm{H}, \mathrm{CH}_{2} \mathrm{SS}\right), 3.35 \\
\left(\mathrm{t}, J=7 \mathrm{~Hz}, 0.166 \mathrm{H}, \mathrm{CH}_{2} \mathrm{Br}\right)\end{array}$ & $\begin{array}{l}29.5\left(\mathrm{CH}_{2} \mathrm{CH}_{2} \mathrm{~S}\right), 32.6 \\
\left(\mathrm{CH}_{2} \mathrm{~S}\right), 37.6\left(\mathrm{CH}_{2} \mathrm{SS}\right)\end{array}$ \\
\hline 4 & $\begin{array}{l}1.70\left(\mathrm{~m}, 4 \mathrm{H}, \mathrm{CH}_{2} \mathrm{CH}_{2} \mathrm{~S}\right), 2.45(\mathrm{t}, J=7 \mathrm{~Hz}, 4 \mathrm{H} \\
\left.\mathrm{CH}_{2} \mathrm{~S}\right), 2.65\left(\mathrm{t}, J=7 \mathrm{~Hz}, 0.372 \mathrm{H}, \mathrm{CH}_{2} \mathrm{SS}\right), 3.35 \\
\left(\mathrm{t}, J=7 \mathrm{~Hz}, 0.093 \mathrm{H}, \mathrm{CH}_{2} \mathrm{Br}\right)\end{array}$ & $28.4\left(\mathrm{CH}_{2} \mathrm{CH}_{2} \mathrm{~S}\right), 32.4\left(\mathrm{CH}_{2} \mathrm{~S}\right)$ \\
\hline 5 & $\begin{array}{l}1.40\left(\mathrm{~m}, 2 \mathrm{H}, \mathrm{CH}_{2} \mathrm{CH}_{2} \mathrm{CH}_{2} \mathrm{~S}\right), 1.50(\mathrm{~m}, 4 \mathrm{H} \\
\left.\mathrm{CH}_{2} \mathrm{CH}_{2} \mathrm{~S}\right), 2.45\left(\mathrm{t}, J=7 \mathrm{~Hz}, 4 \mathrm{H}, \mathrm{CH}_{2} \mathrm{~S}\right), 2.60 \\
\left(\mathrm{t}, J=7 \mathrm{~Hz}, 0.24 \mathrm{H}, \mathrm{CH}_{2} \mathrm{SS}\right), 3.35(\mathrm{t}, J=7 \mathrm{~Hz} \\
\left.0.12 \mathrm{H}, \mathrm{CH}_{2} \mathrm{Br}\right)\end{array}$ & $\begin{array}{l}28.4\left(\mathrm{CH}_{2} \mathrm{CH}_{2} \mathrm{CH}_{2} \mathrm{~S}\right), 29.5 \\
\left(\mathrm{CH}_{2} \mathrm{CH}_{2} \mathrm{~S}\right), 32.4\left(\mathrm{CH}_{2} \mathrm{~S}\right) \\
38.8\left(\mathrm{CH}_{2} \mathrm{SS}\right)\end{array}$ \\
\hline 6 & $\begin{array}{l}1.35\left(\mathrm{~m}, 4 \mathrm{H}, \mathrm{CH}_{2} \mathrm{CH}_{2} \mathrm{CH}_{2} \mathrm{~S}\right), 1.50(\mathrm{~m}, 4 \mathrm{H}, \\
\left.\mathrm{CH}_{2} \mathrm{CH}_{2} \mathrm{~S}\right), 2.45\left(\mathrm{t}, \mathrm{J}=7 \mathrm{~Hz}, 4 \mathrm{H}, \mathrm{CH}_{2} \mathrm{~S}\right), 3.35(\mathrm{t}, \\
\left.J=7 \mathrm{~Hz}, 0.12 \mathrm{H}, \mathrm{CH}_{2} \mathrm{Br}\right)\end{array}$ & $\begin{array}{l}28.4\left(\mathrm{CH}_{2} \mathrm{CH}_{2} \mathrm{CH}_{2} \mathrm{~S}\right), 29.5 \\
\left(\mathrm{CH}_{2} \mathrm{CH}_{2} \mathrm{~S}\right), 32.4\left(\mathrm{CH}_{2} \mathrm{~S}\right)\end{array}$ \\
\hline 7 & $\begin{array}{l}1.20-1.35\left(\mathrm{~m}, 6 \mathrm{H}, \mathrm{CH}_{2} \mathrm{CH}_{2} \mathrm{CH}_{2} \mathrm{CH}_{2} \mathrm{~S} \text { and }\right. \\
\left.\mathrm{CH}_{2} \mathrm{CH}_{2} \mathrm{CH}_{2} \mathrm{~S}\right), 1.50\left(\mathrm{~m}, 4 \mathrm{H}, \mathrm{CH}_{2} \mathrm{CH}_{2} \mathrm{~S}\right), 2.45(\mathrm{t}, \\
\left.J=7 \mathrm{~Hz}, 4 \mathrm{H}, \mathrm{CH}_{2} \mathrm{~S}\right), 2.60(\mathrm{t}, J=7 \mathrm{~Hz}, 0.89 \mathrm{H}, \\
\left.\mathrm{CH}_{2} \mathrm{SS}\right), 3.35\left(\mathrm{t}, J=7 \mathrm{~Hz}, 0.12 \mathrm{H}, \mathrm{CH}_{2} \mathrm{Br}\right)\end{array}$ & $\begin{array}{l}28.1\left(\mathrm{CH}_{2} \mathrm{CH}_{2} \mathrm{CH}_{2} \mathrm{CH}_{2} \mathrm{~S}\right) \\
29.1\left(\mathrm{CH}_{2} \mathrm{CH}_{2} \mathrm{CH}_{2} \mathrm{~S}\right), 29.6 \\
\left(\mathrm{CH}_{2} \mathrm{CH}_{2} \mathrm{~S}\right), 32.1\left(\mathrm{CH}_{2} \mathrm{~S}\right) \\
39.0\left(\mathrm{CH}_{2} \mathrm{SS}\right)\end{array}$ \\
\hline $8^{\mathrm{d}}$ & $\begin{array}{l}1.27-1.45\left(\mathrm{~m}, 8 \mathrm{H}, \mathrm{CH}_{2} \mathrm{CH}_{2} \mathrm{CH}_{2} \mathrm{CH}_{2} \mathrm{~S}\right), 1.50(\mathrm{~m}, \\
\left.4 \mathrm{H}, \mathrm{CH}_{2} \mathrm{CH}_{2} \mathrm{CH}_{2} \mathrm{~S}\right), 2.45(\mathrm{t}, J=7 \mathrm{~Hz}, 4 \mathrm{H}, \\
\left.\mathrm{CH}_{2} \mathrm{~S}\right), 2.65\left(\mathrm{t}, J=7 \mathrm{~Hz}, 0.42 \mathrm{H}, \mathrm{CH}_{2} \mathrm{SS}\right), 3.35 \\
\left(\mathrm{t}, J=7 \mathrm{~Hz}, 0.20 \mathrm{H}, \mathrm{CH}_{2} \mathrm{Br}\right)\end{array}$ & $\begin{array}{l}28.6\left(\mathrm{CH}_{2} \mathrm{CH}_{2} \mathrm{CH}_{2} \mathrm{CH}_{2} \mathrm{~S}\right) \\
29.4\left(\mathrm{CH}_{2} \mathrm{CH}_{2} \mathrm{CH}_{2} \mathrm{~S}\right), 29.7 \\
\left(\mathrm{CH}_{2} \mathrm{CH}_{2} \mathrm{~S}\right), 32.2\left(\mathrm{CH}_{2} \mathrm{~S}\right)\end{array}$ \\
\hline 9 & $\begin{array}{l}\text { 1.16-1.40 (m, } 10 \mathrm{H}, \mathrm{CH}_{2} \mathrm{CH}_{2} \mathrm{CH}_{2} \mathrm{CH}_{2} \mathrm{CH}_{2} \mathrm{~S} \text { and } \\
\left.\mathrm{CH}_{2} \mathrm{CH}_{2} \mathrm{CH}_{2} \mathrm{CH}_{2} \mathrm{~S}\right), 1.50\left(\mathrm{~m}, 4 \mathrm{H}, \mathrm{CH}_{2} \mathrm{CH}_{2} \mathrm{~S}\right), \\
2.45\left(\mathrm{t}, \mathrm{J}=7 \mathrm{~Hz}, 4 \mathrm{H}, \mathrm{CH}_{2} \mathrm{~S}\right), 2.60(\mathrm{t}, J=7 \mathrm{~Hz}, \\
\left.0.8 \mathrm{H}, \mathrm{CH}_{2} \mathrm{SS}\right), 3.35\left(\mathrm{t}, J=7 \mathrm{~Hz}, 0.8 \mathrm{H}, \mathrm{CH}_{2} \mathrm{Br}\right)\end{array}$ & $\begin{array}{l}28.9\left(\mathrm{CH}_{2} \mathrm{CH}_{2} \mathrm{CH}_{2} \mathrm{CH}_{2} \mathrm{CH}_{2} \mathrm{~S}\right), \\
29.2\left(\mathrm{CH}_{2} \mathrm{CH}_{2} \mathrm{CH}_{2} \mathrm{CH}_{2} \mathrm{~S}\right), \\
29.4\left(\mathrm{CH}_{2} \mathrm{CH}_{2} \mathrm{CH}_{2} \mathrm{~S}\right), 29.7 \\
\left(\mathrm{CH}_{2} \mathrm{CH}_{2} \mathrm{~S}\right), 32.2\left(\mathrm{CH}_{2} \mathrm{~S}\right) \\
34.0\left(\mathrm{CH}_{2} \mathrm{Br}\right), 39.5\left(\mathrm{CH}_{2} \mathrm{SS}\right)\end{array}$ \\
\hline 10 & $\begin{array}{l}\left.\text { 1.17-1.25 (m, } 8 \mathrm{H}, \mathrm{CH}_{2} \mathrm{CH}_{2} \mathrm{CH}_{2} \mathrm{CH}_{2} \mathrm{CH}_{2} \mathrm{~S}\right), 1.27- \\
1.40\left(\mathrm{~m}, 4 \mathrm{H}, \mathrm{CH}_{2} \mathrm{CH}_{2} \mathrm{CH}_{2} \mathrm{~S}\right), 1.50(\mathrm{~m}, 4 \mathrm{H}, \\
\left.\mathrm{CH}_{2} \mathrm{CH}_{2} \mathrm{~S}\right), 2.45\left(\mathrm{t}, \mathrm{J}=7 \mathrm{~Hz}, 4 \mathrm{H}, \mathrm{CH}_{2} \mathrm{~S}\right), 2.61(\mathrm{t}, \\
\left.\mathrm{J}=7 \mathrm{~Hz}, 0.27 \mathrm{H}, \mathrm{CH}_{2} \mathrm{SS}\right), 3.35(\mathrm{t}, J=7 \mathrm{~Hz}, 0.86 \\
\left.\mathrm{H}, \mathrm{CH}_{2} \mathrm{Br}\right)\end{array}$ & $\begin{array}{l}28.9\left(\mathrm{CH}_{2} \mathrm{CH}_{2} \mathrm{CH}_{2} \mathrm{CH}_{2} \mathrm{CH}_{2} \mathrm{~S}\right), \\
29.2\left(\mathrm{CH}_{2} \mathrm{CH}_{2} \mathrm{CH}_{2} \mathrm{CH}_{2} \mathrm{~S}\right), \\
29.5\left(\mathrm{CH}_{2} \mathrm{CH}_{2} \mathrm{CH}_{2} \mathrm{~S}\right), 29.7 \\
\left(\mathrm{CH}_{2} \mathrm{CH}_{2} \mathrm{~S}\right), 32.2\left(\mathrm{CH}_{2} \mathrm{~S}\right) \\
34.2\left(\mathrm{CH}_{2} \mathrm{Br}\right), 39.5\left(\mathrm{CH}_{2} \mathrm{SS}\right)\end{array}$ \\
\hline 14 & $\begin{array}{l}1.90\left(\mathrm{~m}, 4 \mathrm{H}, \mathrm{CH}_{2} \mathrm{CH}_{2} \mathrm{~S}\right), 2.65(\mathrm{t}, J=7 \mathrm{~Hz}, 4 \mathrm{H} \\
\left.\mathrm{CH}_{2} \mathrm{~S}\right), 2.65\left(\mathrm{t}, J=7 \mathrm{~Hz}, 0.344 \mathrm{H}, \mathrm{CH}_{2} \mathrm{SS}\right), 3.50 \\
\left(\mathrm{t}, J=7 \mathrm{~Hz}, 0.086 \mathrm{H}, \mathrm{CH}_{2} \mathrm{Cl}\right)\end{array}$ & $\begin{array}{l}28.4\left(\mathrm{CH}_{2} \mathrm{CH}_{2} \mathrm{~S}\right), 32.4 \\
\left(\mathrm{CH}_{2} \mathrm{~S}\right), 38.5\left(\mathrm{CH}_{2} \mathrm{SS}\right)\end{array}$ \\
\hline 15 & $\begin{array}{l}1.40\left(\mathrm{~m}, 2 \mathrm{H}, \mathrm{CH}_{2} \mathrm{CH}_{2} \mathrm{CH}_{2} \mathrm{~S}\right), 1.50(\mathrm{~m}, 4 \mathrm{H}, \\
\left.\mathrm{CH}_{2} \mathrm{CH}_{2} \mathrm{~S}\right), 2.45\left(\mathrm{t}, J=7 \mathrm{~Hz}, 4 \mathrm{H}, \mathrm{CH}_{2} \mathrm{~S}\right), 2.60(\mathrm{t}, \\
\left.J=7 \mathrm{~Hz}, 0.416 \mathrm{H}, \mathrm{CH}_{2} \mathrm{SS}\right), 3.50(\mathrm{t}, J=7 \mathrm{~Hz}, \\
\left.0.157 \mathrm{H}, \mathrm{CH}_{2} \mathrm{Cl}\right)\end{array}$ & $\begin{array}{l}28.4\left(\mathrm{CH}_{2} \mathrm{CH}_{2} \mathrm{CH}_{2} \mathrm{~S}\right), 29.5 \\
\left(\mathrm{CH}_{2} \mathrm{CH}_{2} \mathrm{~S}\right), 32.4\left(\mathrm{CH}_{2} \mathrm{~S}\right)\end{array}$ \\
\hline 16 & $\begin{array}{l}1.35\left(\mathrm{~m}, 4 \mathrm{H}, \mathrm{CH}_{2} \mathrm{CH}_{2} \mathrm{CH}_{2} \mathrm{~S}\right), 1.50(\mathrm{~m}, 4 \mathrm{H}, \\
\left.\mathrm{CH}_{2} \mathrm{CH}_{2} \mathrm{~S}\right), 2.45\left(\mathrm{t}, J=7 \mathrm{~Hz}, 4 \mathrm{H}, \mathrm{CH}_{2} \mathrm{~S}\right), 2.60(\mathrm{t}, \\
\left.J=7 \mathrm{~Hz}, 0.393 \mathrm{H}, \mathrm{CH}_{2} \mathrm{SS}\right), 3.50(\mathrm{t}, J=7 \mathrm{~Hz}, \\
\left.0.304 \mathrm{H}, \mathrm{CH}_{2} \mathrm{Cl}\right)\end{array}$ & $\begin{array}{l}28.4\left(\mathrm{CH}_{2} \mathrm{CH}_{2} \mathrm{CH}_{2} \mathrm{~S}\right), 29.52 \\
\left(\mathrm{CH}_{2} \mathrm{CH}_{2} \mathrm{~S}\right), 32.4\left(\mathrm{CH}_{2} \mathrm{~S}\right) \\
38.5\left(\mathrm{CH}_{2} \mathrm{SS}\right), 44.5\left(\mathrm{CH}_{2} \mathrm{Cl}\right)\end{array}$ \\
\hline 17 & 1.20-1.42(m, $\left.8 \mathrm{H}, \mathrm{CH}_{2} \mathrm{CH}_{2} \mathrm{CH}_{2} \mathrm{CH}_{2} \mathrm{~S}\right), 1.50(\mathrm{~m}$, & $28.6\left(\mathrm{CH}_{2} \mathrm{CH}_{2} \mathrm{CH}_{2} \mathrm{CH}_{2} \mathrm{~S}\right)$ \\
\hline
\end{tabular}




\begin{tabular}{|c|c|c|}
\hline & $\begin{array}{l}\left.4 \mathrm{H}, \mathrm{CH}_{2} \mathrm{CH}_{2} \mathrm{CH}_{2} \mathrm{~S}\right), 2.45(\mathrm{t}, J=7 \mathrm{~Hz}, 4 \mathrm{H}, \\
\left.\mathrm{CH}_{2} \mathrm{~S}\right), 2.60\left(\mathrm{t}, J=7 \mathrm{~Hz}, 0.834 \mathrm{H}, \mathrm{CH}_{2} \mathrm{SS}\right), 3.50 \\
\left(\mathrm{t}, J=7 \mathrm{~Hz}, 1.57 \mathrm{H}, \mathrm{CH}_{2} \mathrm{Cl}\right)\end{array}$ & $\begin{array}{l}29.4\left(\mathrm{CH}_{2} \mathrm{CH}_{2} \mathrm{CH}_{2} \mathrm{~S}\right), 29.7 \\
\left(\mathrm{CH}_{2} \mathrm{CH}_{2} \mathrm{~S}\right), 32.2\left(\mathrm{CH}_{2} \mathrm{~S}\right) \\
39.0\left(\mathrm{CH}_{2} \mathrm{SS}\right), 45.0\left(\mathrm{CH}_{2} \mathrm{Cl}\right)\end{array}$ \\
\hline 19 & $\begin{array}{l}0.95\left(\mathrm{t}, J=7 \mathrm{~Hz}, 1.27 \mathrm{H}, \mathrm{CH}_{3} \mathrm{CH}_{2} \mathrm{CH}_{2} \mathrm{CH}_{2} \mathrm{~S}\right), \\
1.45\left(\mathrm{~m}, 0.85 \mathrm{H}, \mathrm{CH}_{3} \mathrm{CH}_{2} \mathrm{CH}_{2} \mathrm{CH}_{2} \mathrm{~S}\right), 1.61(\mathrm{~m}, \\
\left.0.85 \mathrm{H}, \mathrm{CH}_{3} \mathrm{CH}_{2} \mathrm{CH}_{2} \mathrm{CH}_{2} \mathrm{~S}\right), 2.55(\mathrm{t}, 0.85 \mathrm{H}, J=7 \\
\left.\mathrm{Hz}, \mathrm{CH}_{3} \mathrm{CH}_{2} \mathrm{CH}_{2} \mathrm{CH}_{2} \mathrm{~S}\right), 2.80\left(\mathrm{~s}, 4 \mathrm{H}, \mathrm{CH}_{2} \mathrm{~S}\right)\end{array}$ & $\begin{array}{l}\text { 13.6 }\left(\mathrm{CH}_{3} \mathrm{CH}_{2} \mathrm{CH}_{2} \mathrm{CH}_{2} \mathrm{~S}\right) \\
\text { 22.1 }\left(\mathrm{CH}_{3} \mathrm{CH}_{2} \mathrm{CH}_{2} \mathrm{CH}_{2} \mathrm{~S}\right) \\
\text { 29.3 }\left(\mathrm{CH}_{3} \mathrm{CH}_{2} \mathrm{CH}_{2} \mathrm{CH}_{2} \mathrm{~S}\right) \\
\text { 31.0 }\left(\mathrm{CH}_{3} \mathrm{CH}_{2} \mathrm{CH}_{2} \mathrm{CH}_{2} \mathrm{~S}\right) \\
\text { 32.4 }\left(\mathrm{CH}_{2} \mathrm{~S}\right) .\end{array}$ \\
\hline 20 & $\begin{array}{l}1.20\left[\mathrm{~d}, J=7 \mathrm{~Hz}, 4 \mathrm{H}, \mathrm{CH}\left(\mathrm{CH}_{3}\right)_{2} \mathrm{~S}\right], 2.71(\mathrm{~s}, 4 \mathrm{H}, \\
\left.\mathrm{CH}_{2} \mathrm{~S}\right), 2.90\left[\mathrm{~m}, 0.67 \mathrm{H}, \mathrm{CH}\left(\mathrm{CH}_{3}\right)_{2} \mathrm{~S}\right]\end{array}$ & $\begin{array}{l}23.4 .8\left[\mathrm{CH}\left(\mathrm{CH}_{3}\right)_{2} \mathrm{~S}\right], 32.4 \\
{\left[\mathrm{CH}\left(\mathrm{CH}_{3}\right)_{2} \mathrm{~S}\right], 35.1\left(\mathrm{CH}_{2} \mathrm{~S}\right)}\end{array}$ \\
\hline 21 & $\begin{array}{l}0.95\left(\mathrm{t}, J=7 \mathrm{~Hz}, 1.27 \mathrm{H}, \mathrm{CH}_{3} \mathrm{CH}_{2} \mathrm{CH}_{2} \mathrm{CH}_{2} \mathrm{~S}\right), \\
1.45\left(\mathrm{~m}, 0.85 \mathrm{H}, \mathrm{CH}_{3} \mathrm{CH}_{2} \mathrm{CH}_{2} \mathrm{CH}_{2} \mathrm{~S}\right), 1.61(\mathrm{~m}, \\
\left.0.85 \mathrm{H}, \mathrm{CH}_{3} \mathrm{CH}_{2} \mathrm{CH}_{2} \mathrm{CH}_{2} \mathrm{~S}\right), 2.55(\mathrm{t}, J=7 \mathrm{~Hz}, \\
\left.0.85 \mathrm{H}, \mathrm{CH}_{3} \mathrm{CH}_{2} \mathrm{CH}_{2} \mathrm{CH}_{2} \mathrm{~S}\right), 2.8\left(\mathrm{~s}, 4 \mathrm{H}, \mathrm{CH}_{2} \mathrm{~S}\right)\end{array}$ & $\begin{array}{l}\text { 13.6 }\left(\mathrm{CH}_{3} \mathrm{CH}_{2} \mathrm{CH}_{2} \mathrm{CH}_{2} \mathrm{~S}\right) \\
22.1\left(\mathrm{CH}_{3} \mathrm{CH}_{2} \mathrm{CH}_{2} \mathrm{CH}_{2} \mathrm{~S}\right) \\
29.3\left(\mathrm{CH}_{3} \mathrm{CH}_{2} \mathrm{CH}_{2} \mathrm{CH}_{2} \mathrm{~S}\right) \\
31.0\left(\mathrm{CH}_{3} \mathrm{CH}_{2} \mathrm{CH}_{2} \mathrm{CH}_{2} \mathrm{~S}\right) \\
\text { 32.4 }\left(\mathrm{CH}_{2} \mathrm{~S}\right)\end{array}$ \\
\hline 22 & $\begin{array}{l}0.95\left(\mathrm{t}, J=7 \mathrm{~Hz}, 0.70 \mathrm{H}, \mathrm{CH}_{3} \mathrm{CH}_{2}\right), 1.22(\mathrm{~d}, J= \\
7 \mathrm{~Hz}, 0.70 \mathrm{H}, \mathrm{CH} \mathrm{CHS}), 1.50(\mathrm{~m}, 0.47 \mathrm{H}, \\
\left.\mathrm{CH}_{3} \mathrm{CH}_{2}\right), 2.70\left(\mathrm{~m}, 0.23 \mathrm{H}, \mathrm{CH}_{3} \mathrm{CHS}\right), 2.85(\mathrm{~s}, 4 \\
\left.\mathrm{H}, \mathrm{CH}_{2} \mathrm{~S}\right)\end{array}$ & $\begin{array}{l}22.9\left(\mathrm{CH}_{3} \mathrm{CH}_{2}\right), 30.8 \\
{\left[\mathrm{CH}_{2} \mathrm{CH}\left(\mathrm{CH}_{3}\right) \mathrm{S}\right], 32.4} \\
\left(\mathrm{CH}_{3} \mathrm{CHS}\right), 35.1\left(\mathrm{CH}_{2} \mathrm{~S}\right)\end{array}$ \\
\hline
\end{tabular}

Notes: ${ }^{\text {a }}$ Polymeric sulfides $\mathbf{1 , 2}$ and 13 were highly insoluble in most solvents and no NMR spectra were recorded.

${ }^{\mathrm{b}} \mathrm{CH}_{2} \mathrm{X}(\mathrm{X}=\mathrm{Br}, \mathrm{Cl})$ represents the terminal $\mathrm{CH}_{2}$ of the polymer and the $\mathrm{CH}_{2} \mathrm{SS}$ represents the disulfide. The term $\mathrm{CH}_{2} \mathrm{~S}$ refers to signals next to sulfide sulfur, $\mathrm{CH}_{2} \mathrm{SCH}_{2}$.

${ }^{c}$ In some cases the signals for the $\mathrm{CH}_{2} \mathrm{X}$ and the $\mathrm{CH}_{2} \mathrm{SS}$ were not noticeable.

${ }^{\mathrm{d}} \mathrm{NMR}$ for the polymeric material $\mathbf{8}$ obtained when the reaction time was $16 \mathrm{~h}$. 
K. Smith et al.

\section{List of Schemes and Figures Captions}

Scheme 1. Synthesis of poly(alkylene sulfide)s 1-10 from polycondensation of dibromoalkanes with $\mathrm{Na}_{2} \mathrm{~S} .9 \mathrm{H}_{2} \mathrm{O}$.

Scheme 2. Synthesis of poly(alkylene sulfide)s 13-17 from polycondensation of dichloroalkanes and $\mathrm{Na}_{2} \mathrm{~S} .9 \mathrm{H}_{2} \mathrm{O}$.

Scheme 3. Synthesis of poly(alkylene sulfide)s 19-22 from polycondensation of 1,2-dichloroethane and $\mathrm{Na}_{2} \mathrm{~S} .9 \mathrm{H}_{2} \mathrm{O}$ in the presence of haloalkanes.

Figure 1. Structures of tetrahydrothiophene (11) and 1,2-dithiane (12)

Figure 2. $\quad$ Structure of 1,2-dithiocane (18)

Figure 3. Total yields of polymeric materials 19-22 obtained from polycondensation of 1,2-dichloroethane and $\mathrm{Na}_{2} \mathrm{~S} .9 \mathrm{H}_{2} \mathrm{O}$ in the presence of haloalkanes under reflux conditions. 